\title{
Adapting Inhaled Medication Practice in COPD and Asthma to Avoid Funding the Tobacco Industry
}

\author{
Toby GD Capstick $\mathbb{D}^{\prime}$ \\ Nicholas S Hopkinson (iD ${ }^{2}$ \\ 'Respiratory Medicine, Leeds Teaching \\ Hospitals NHS Trust, Leeds, UK; \\ ${ }^{2}$ National Heart and Lung Institute, \\ Imperial College, London, UK
}

\begin{abstract}
The takeover of Vectura, a healthcare company specialising in inhaled medication, by Philip Morris International raises serious ethical concerns. The European Respiratory Society notes that "health professionals will avoid prescribing drugs from any company that enriches the tobacco industry due to the ethical implications". People with chronic obstructive pulmonary disease (COPD) and asthma will also be reluctant to use medications which profit a company that is estimated to kill at least one million people every year. We discuss the practicalities involved in switching people with lung disease to inhaled medications that are not tobacco industry linked. Potential alternative inhaled medications are set out, which are likely to be equally effective for most patients. A consideration of beneficence, nonmaleficence, autonomy, and distributive justice demonstrates strong ethical reasons to support switching away from the prescription of tobacco industry linked products.
\end{abstract}

Keywords: ethics, corporate social responsibility, public health

\section{Introduction}

The 2018 Cape Town Declaration identifies the activities of the tobacco industry as incompatible with the human right to health. ${ }^{1}$ The Global Burden of Disease Study estimates the annual global death toll from smoking to be 8.71 million. ${ }^{2}$ Through the cultivation, production, processing and disposal of its products, the industry creates a substantial burden on the environment, which falls mainly in low and middle-income countries. ${ }^{3}$ Tobacco multinationals stand condemned as a major obstacle to the achievement of the UN's sustainable development goals. ${ }^{4}$

Based on its market share of at least $12 \%$ of cigarettes sold worldwide, (https:// tobaccotactics.org/wiki/philip-morris-international/), Philip Morris International (PMI) kills more than a million people every year. Although claiming to wish to end the use of combustible cigarettes, PMI accounts show that it shipped 151 billion cigarettes in quarter one of 2020 increasing to 156 billion for the same period in 2021. PMI's takeover of Vectura, an inhaler company whose technologies are used by people with COPD and asthma, conditions caused and aggravated by its products, is therefore a cause for concern. ${ }^{6}$ A range of consequences follow from such a takeover. Having become part of the tobacco industry, Vectura, its employees, and anyone continuing to work for or collaborate with Vectura, are excluded from membership of respiratory professional societies as well as collaboration with academic institutions, on grants and from publication in
Correspondence: Nicholas S Hopkinson National Heart and Lung Institute, Imperial College, London, Royal Brompton Hospital Campus, Fulham Road, London, SW3 6NP, UK

Email n.hopkinson@ic.ac.Uk 
medical journals. ${ }^{7,8}$ The details of these policies vary, but as an example, the European Respiratory Society excludes anyone with tobacco industry links in the last 10 years. Many Vectura scientists will choose to leave rather than face long-term pariah status. Policies that exclude the tobacco industry from interaction with government (Article 5.3 of the WHO's Framework Convention on Tobacco Control) will also apply to Vectura.

Vectura receives income from the sale of a range of inhalers currently in widespread use. Responding to the takeover by PMI, The European Respiratory Society states that "health professionals will avoid prescribing drugs from any company that enriches the tobacco industry due to the ethical implications". ${ }^{7}$ Patients with lung disease are also likely to be reluctant to use tobacco industry linked devices.

We discuss the ethical issues raised around choice of medication in this context, and present potential alternative medications for clinicians, commissioners and patients considering switching.

\section{Inhalers Associated with Vectura}

The Vectura website states that their "combination of formulation science, device technology and inhaled development expertise has contributed to the success of 13 inhaled medicines, launched by our partners and licensees. Since launch, they have generated $\$ 11$ billion in sales and in 2020 these products were used by 10 million patients worldwide". 9 The products are set out in Table 1 and Figure 1, based on the Vectura Group plc Annual Report and Accounts 2020. ${ }^{10}$ The Vectura accounts report revenue income in 2020 for Flutiform, royalty and other marketed revenues for the GSK Ellipta, Novartis Breezhaler, Hikma generic Advair programme, and Sandoz Forspiro. The Vectura website describes their role in the development of these products as contributing to the formulation of the GSK Ellipta and Novartis Breezhaler, and the formulation, device and development of Flutiform pMDI, Flutiform k-haler and Sandoz Forspiro. ${ }^{9}$

Data from the NHS Business Services Authority (https://www.nhsbsa.nhs.uk/statistical-collections/prescrip tion-cost-analysis-england/prescription-cost-analysis-

england-202021) show that in 2020, English primary care spend on inhalers totalled $£ 960.5$ million. The Vecturalinked products listed equate to $£ 177$ million - almost a fifth of total inhaler expenditure.

Fortunately, over 120 inhaled products are now licensed for the treatment of asthma and COPD in the
Table I Current Approved Inhaled Medicines Associated with Vectura

\begin{tabular}{|l|l|}
\hline Product & $\begin{array}{l}\text { Manufacturer(s)/ } \\
\text { Partners }\end{array}$ \\
\hline Flutiform pMDI & $\begin{array}{l}\text { Kyorin (Japan) } \\
\text { MundiPharma }\end{array}$ \\
\hline Flutiform K-haler & MundiPharma \\
\hline Ultibro Breezhaler & Novartis \\
\hline Seebri Breezhaler & Novartis \\
\hline Enerzair Breezhaler & Novartis \\
\hline AirFluSal Forspiro & Sandoz \\
\hline AirBuFo Forspiro ${ }^{\ddagger}$ & Sandoz \\
\hline $\begin{array}{l}\text { Fluticasone Propionate and } \\
\text { Salmeterol* }\end{array}$ & Hikma (US) \\
\hline Breelib ${ }^{\dagger}$ & Bayer \\
\hline Incruse Ellipta & GSK \\
\hline Anoro Ellipta & GSK \\
\hline Relvar/Breo Ellipta & GSK \\
\hline Trelegy Ellipta & GSK \\
\hline Notes: Infrmato a & \\
\hline
\end{tabular}

Notes: Information adapted from Vectura accounts. ${ }^{10} *$ Hikma Pharmaceuticals plc announced that they had resumed the launch of a generic version of Advair diskus in the US. ${ }^{23}{ }^{\dagger}$ Breelib is a nebuliser approved for the administration of iloprost $\left(\right.$ Ventavis $\left.^{\circledR}\right)$ and generic lloprost Zentiva nebuliser solution to adult patients with primary pulmonary hypertension. ${ }^{\ddagger}$ AirBuFo Forspiro is authorised in a number of Member States of the EEA, including Belgium, Denmark, France, Ireland, Italy, Norway, Portugal, Spain, Sweden ${ }^{24}$.

UK, so there are likely to be several suitable alternatives for patients that healthcare professionals can prescribe, to avoid directing income to the tobacco industry. Some examples are set out in Table 2, These are illustrative, based on UK prescribing, and given variation in local availability and licensing the range of options may be different in other countries.

Inevitably, a change in prescribing policy will require switching some individuals to alternative preparations and different inhaler devices. It may also require a change in the inhaled $\operatorname{drug}(\mathrm{s})$ to different ones in the same class. It is important therefore, that proposed changes are performed in collaboration with each patient as a partner, using the principles of shared decision making. ${ }^{11}$ Changes in inhaled therapy will require careful discussion with patients about the reasons for such a change, potential available options and their agreement to switch. 


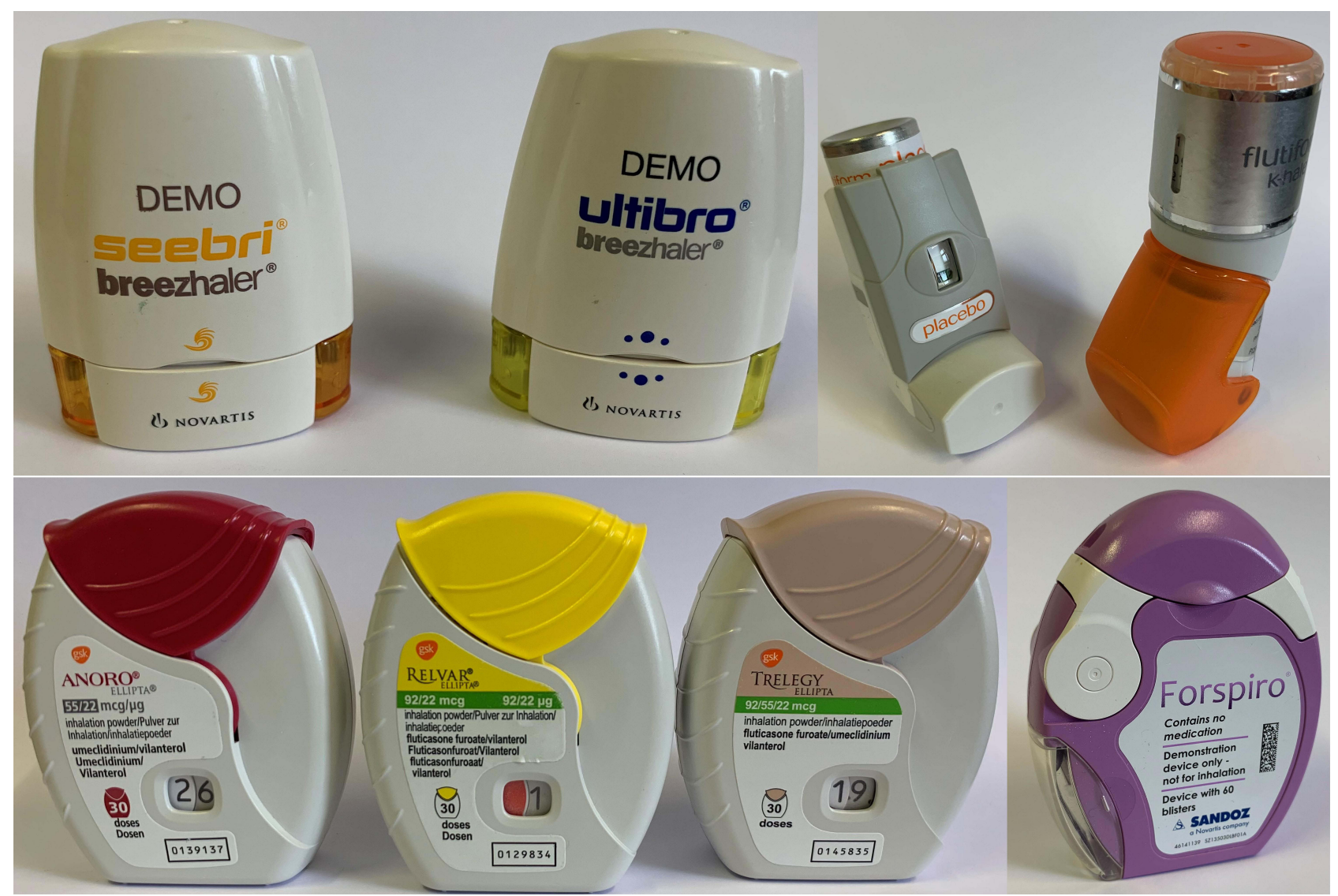

Figure I Inhaler devices listed in the Vectura accounts as generating revenue, or income from "royalty \& other marketed revenues". https://www.vectura.com/wp-content/ uploads/2021/04/Vectura-Group-plc-Annual-Report-and-Accounts-2020.pdf- clockwise from top left: Novartis Breezhalers, Mundipharma Flutiform k-haler, Sandoz AirFluSal Forspiro, GSK Ellipta inhalers.

\section{Ethical Considerations}

Ethical issues in medicine, such as those arising here around avoiding or switching away from inhaled medications whose use provides an income stream to the tobacco industry, can be considered in terms of four principles beneficence, non-maleficence, autonomy, and distributive justice.

\section{Beneficence}

Protecting people with lung disease from the moral distress of having to use inhalers that fund the tobacco industry, an industry which is a key cause of the development and progression of lung disease, is an important benefit of avoiding these products. So too is reinforcing the policy that the tobacco industry needs to be excluded from healthcare, based on its long and extensively documented history of dishonesty and diversion around the harms of smoking. It challenges the attempt by the industry to divert attention from the actions that are actually needed to end smoking, achieving the UK's Smokefree 2030 ambition, such as a polluter-pays levy on tobacco industry profits and raising the legal age of sale to $21 .^{12}$

\section{Non-Maleficence}

The key concern is that individual patients might come to harm the use of alternative inhalers. However, as outlined in the previous section, the diversity of the inhaler market means that a range of alternatives in the same class(es), that are likely to be equally effective, are available. It is worth noting that commissioning bodies have a history of mandating wholesale inhaler switching for populations, often for reasons of economy.

It should be acknowledged that there is a degree of idiosyncrasy in response to inhaled medications, even in the same class, as well as variation in the ability to use a particular inhaler device. The objective is to avoid tobacco industry linked devices wherever possible rather than absolutely prohibit their use, to allow for the occasional instance where not using them would genuinely cause a deterioration in an individual patient's condition. 
Table 2 Potential Alternatives to Inhalers for COPD and Asthma That are Not Associated with Vectura

\begin{tabular}{|c|c|c|c|c|}
\hline $\begin{array}{l}\text { Brand } \\
\text { Name }\end{array}$ & Generic Drugs & Licence & $\begin{array}{l}\text { Manufacturerl } \\
\text { Partners }\end{array}$ & Alternative Options \\
\hline $\begin{array}{l}\text { Flutiform } \\
\text { pMDI }\end{array}$ & $\begin{array}{l}\text { Fluticasone Propionate/ } \\
\text { Formoterol }\end{array}$ & Asthma & $\begin{array}{l}\text { Kyorin } \\
\text { MundiPharma }\end{array}$ & $\begin{array}{l}\text { No alternatives in same drug combination. Alternatives in } \\
\text { PMDI include } \\
\text { - beclometasone/formoterol (Fostair }{ }^{\circledR} \text {, Luforbec }{ }^{\circledR} \text { ) } \\
\text { - Fluticasone Propionate/salmeterol (AirFluSal }{ }^{\circledR}, \text { Aloflute }{ }^{\circledR} \text {, } \\
\text { Combisal }^{\circledR}, \text { Sereflo }{ }^{\circledR}, \text { Seretide }{ }^{\circledR}, \text { Sirdupla }{ }^{\circledR} \text { ) - NB. Not all } \\
\text { brands available in low, medium and high dose ICS. } \\
\left.\text { - Budesonide/formoterol (Symbicort }{ }^{\circledR}\right) \text {. NB. Only available } \\
\text { in two strengths (low and medium dose), and with HFA } \\
227 \text { propellant with a very high carbon impact. }\end{array}$ \\
\hline $\begin{array}{l}\text { Flutiform } \\
\text { K-haler }\end{array}$ & $\begin{array}{l}\text { Fluticasone Propionate/ } \\
\text { Formoterol }\end{array}$ & Asthma & MundiPharma & $\begin{array}{l}\text { Flutiform K-haler discontinued in UK April 202I. No ICS/ } \\
\text { LABA available in breath-actuated PMDI devices. } \\
\text { For alternatives in pMDI, see Flutiform pMDI, above. }\end{array}$ \\
\hline $\begin{array}{l}\text { Ultibro } \\
\text { Breezhaler }\end{array}$ & Indacaterol/glycopyrronium & COPD & Novartis & $\begin{array}{l}\text { DPI alternative: } \\
\text { - Duaklir Genuair (formoterol/aclidinium) } \\
\text { Aerosol alternatives: } \\
\text { - Bevespi Aerosphere pMDI (formoterol/glycopyrronium) } \\
\text { - Spiolto Respimat (olodaterol/tiotropium) }\end{array}$ \\
\hline $\begin{array}{l}\text { Seebri } \\
\text { Breezhaler }\end{array}$ & Glycopyrronium & COPD & Novartis & $\begin{array}{l}\text { DPI alternative: } \\
\text { - Eklira Genuair (aclidinium) } \\
\text { - Tiotropium (Spiriva }{ }^{\circledR} \text { HandiHaler, Braltus }{ }^{\circledR} \text { Zonda, } \\
\text { Tiogiva }{ }^{\circledR} \text { MRX003-R inhaler, Acopair }{ }^{\circledR} \text { NeumoHaler) } \\
\text { Aerosol alternative: } \\
\text { - Spiriva Respimat (tiotropium) }\end{array}$ \\
\hline $\begin{array}{l}\text { Enerzair } \\
\text { Breezhaler }\end{array}$ & $\begin{array}{l}\text { Mometasone/Indacaterol/ } \\
\text { glycopyrronium }\end{array}$ & Asthma & Novartis & $\begin{array}{l}\text { There are no alternative ICS/LABA/LAMA DPI inhalers } \\
\text { licensed for use in asthma. DPI alternatives would require } \\
\text { use of a suitable ICS/LABA DPI in combination with Spiriva } \\
\text { Respimat (the only licensed LAMA for asthma). } \\
\text { Aerosol alternative: } \\
\text { - Trimbow MDI (budesonide/formoterol/glycopyrronium). } \\
\text { NB. Trimbow is licensed in asthma as a medium dose } \\
\text { ICS, whilst Enerzair is a high dose ICS, so a switch would } \\
\text { represent an ICS dose reduction. }\end{array}$ \\
\hline $\begin{array}{l}\text { AirFluSal } \\
\text { Forspiro }\end{array}$ & $\begin{array}{l}\text { Fluticasone Propionate/ } \\
\text { Salmeterol }\end{array}$ & $\begin{array}{l}\text { Asthma, } \\
\text { COPD }\end{array}$ & Sandoz & $\begin{array}{l}\text { Alternative DPIs include: } \\
\text { - Fluticasone Propionate/Salmeterol DPIs: Seretide }{ }^{\circledR} \\
\text { Accuhaler, Fixkoh }{ }^{\circledR} \text { Airmaster, Fusacomb }{ }^{\circledR} \text { Easyhaler, } \\
\text { Stalpex }{ }^{\circledR} \text { G7 inhaler } \\
\text { Alternative DPls for other ICS/LABA drugs include: } \\
\text { - Budesonide/formoterol: DuoResp }{ }^{\circledR} \text { Spiromax, Fobumix }{ }^{\circledR} \\
\text { Easyhaler, Symbicort }{ }^{\circledR} \text { Turbohaler } \\
\text { Beclometasone/formoterol: (Fostair }{ }^{\circledR} \text { NEXThaler) }\end{array}$ \\
\hline
\end{tabular}

(Continued) 
Table 2 (Continued).

\begin{tabular}{|c|c|c|c|c|}
\hline $\begin{array}{l}\text { Brand } \\
\text { Name }\end{array}$ & Generic Drugs & Licence & $\begin{array}{l}\text { Manufacturerl } \\
\text { Partners }\end{array}$ & Alternative Options \\
\hline $\begin{array}{l}\text { AirBuFo } \\
\text { Forspiro }\end{array}$ & Budesonide/formoterol & $\begin{array}{l}\text { Asthma, } \\
\text { COPD }\end{array}$ & Sandoz & $\begin{array}{l}\text { Not licensed in the UK. } \\
\text { Alternative DPIs include: } \\
\text { - Budesonide/formoterol: DuoResp }{ }^{\circledR} \text { Spiromax, Fobumix }{ }^{\circledR} \\
\text { Easyhaler, Symbicort }{ }^{\circledR} \text { Turbohaler } \\
\text { Alternative DPIs for other ICS/LABA drugs include: } \\
\text { - Beclometasone/formoterol: (Fostair }{ }^{\circledR} \text { NEXThaler) } \\
\text { Fluticasone Propionate/Salmeterol DPIs: Seretide }{ }^{\circledR} \\
\text { Accuhaler, Fixkoh }{ }^{\circledR} \text { Airmaster, Fusacomb }{ }^{\circledR} \text { Easyhaler, } \\
\text { Stalpex }{ }^{\circledR} \text { G7 inhaler }\end{array}$ \\
\hline $\begin{array}{l}\text { Fluticasone } \\
\text { Propionate } \\
\text { and } \\
\text { Salmeterol* }\end{array}$ & $\begin{array}{l}\text { Fluticasone Propionate/ } \\
\text { Salmeterol }\end{array}$ & $\begin{array}{l}\text { Asthma, } \\
\text { COPD }\end{array}$ & Hikma & $\begin{array}{l}\text { Not licensed in the UK. } \\
\text { Alternative DPIs include: } \\
\text { Fluticasone Propionate/Salmeterol DPls: Seretide }{ }^{\circledR} \\
\text { Accuhaler, Fixkoh }{ }^{\circledR} \text { Airmaster, Fusacomb }{ }^{\circledR} \text { Easyhaler, } \\
\text { Stalpex }{ }^{\circledR} \text { G7 inhaler }\end{array}$ \\
\hline Breelib† & $\begin{array}{l}\text { Nebuliser for administration } \\
\text { of Ventavis (iloprost), or } \\
\text { generic lloprost Zentiva }\end{array}$ & $\begin{array}{l}\text { Pulmonary } \\
\text { Hypertension }\end{array}$ & Bayer & $\begin{array}{l}\text { No other licensed iloprost nebuliser solution preparations } \\
\text { available }\end{array}$ \\
\hline Incruse Ellipta & Umeclidinium & COPD & GSK & $\begin{array}{l}\text { DPI alternative: } \\
\text { - Eklira Genuair (aclidinium) } \\
\text { - Tiotropium (Spiriva }{ }^{\circledR} \text { HandiHaler, Braltus }{ }^{\circledR} \text { Zonda, } \\
\text { Tiogiva }{ }^{\circledR} \text { MRX003-R inhaler, Acopair }{ }^{\circledR} \text { NeumoHaler) } \\
\text { Aerosol alternative: } \\
\text { - Spiriva Respimat (tiotropium) }\end{array}$ \\
\hline Anoro Ellipta & Vilanterol/Umeclidinium & COPD & GSK & $\begin{array}{l}\text { DPI alternative: } \\
\text { - Duaklir Genuair (formoterol/aclidinium) } \\
\text { Aerosol alternatives: } \\
\text { - Bevespi Aerosphere pMDI (formoterol/glycopyrronium) } \\
\text { - Spiolto Respimat (olodaterol/tiotropium) }\end{array}$ \\
\hline $\begin{array}{l}\text { Relvar/Breo } \\
\text { Ellipta }\end{array}$ & Fluticasone furoate/vilanterol & $\begin{array}{l}\text { Asthma, } \\
\text { COPD }\end{array}$ & GSK & $\begin{array}{l}\text { No alternatives in same drug combination. DPI } \\
\text { alternatives: } \\
\text { - Fluticasone Propionate/Salmeterol DPls: Seretide }{ }^{\circledR} \\
\text { Accuhaler, Fixkoh }{ }^{\circledR} \text { Airmaster, Fusacomb }{ }^{\circledR} \text { Easyhaler, } \\
\text { Stalpex }{ }^{\circledR} \text { G7 inhaler } \\
\text { - Budesonide/formoterol: DuoResp }{ }^{\circledR} \text { Spiromax, Fobumix }{ }^{\circledR} \\
\text { Easyhaler, Symbicort }{ }^{\circledR} \text { Turbohaler } \\
\text { - Beclometasone/formoterol: (Fostair }{ }^{\circledR} \text { NEXThaler) }\end{array}$ \\
\hline Trelegy Ellipta & $\begin{array}{l}\text { Fluticasone furoate/vilanterol/ } \\
\text { glycopyrronium }\end{array}$ & COPD & GSK & $\begin{array}{l}\text { DPI alternative: } \\
\text { - Trimbow NEXThaler (budesonide/formoterol/ } \\
\text { glycopyrronium). Available from September 202I. } \\
\text { Aerosol alternatives: } \\
\text { - Trimbow MDI (budesonide/formoterol/glycopyrronium). }\end{array}$ \\
\hline
\end{tabular}

Notes: The table is illustrative, and the alternatives suggested are based on UK prescribing. Given local availability and licensing the range of options may be different in other countries. 
To avoid harm, when someone commences inhaled therapy, or when they switch to a different device, it is essential that inhaler technique is taught and checked to ensure that it is used correctly. ${ }^{13-15} \mathrm{An}$ assessment of each patient's inspiratory capacity to use either a dry powder inhaler or an aerosol device (pMDI, breath-actuated pMDI or soft mist inhaler) should be made to determine the most appropriate type of device to prescribe. ${ }^{16}$ The use of low carbon inhaler devices may be prioritised in patients able to use dry powder or soft mist inhalers, but if not, then pMDIs should be used.

\section{Autonomy}

Public attitudes to the tobacco industry are negative, with only $9 \%$ believing that tobacco companies behave ethically and $6 \%$ that they can be trusted to tell the truth. ${ }^{17}$ People with lung disease, particularly where it is directly linked to smoking, are likely to want to avoid products that fund the tobacco industry as a matter of moral choice. There is evidence that patients consider environmental impact of treatments to be of importance. ${ }^{18}$ As one person with asthma writes; "2nd hand smoke has put me in ICU ... I am not ok with using a device that is associated with a tobacco company". ${ }^{19}$

Some individuals on tobacco-industry linked inhalers who are well-controlled may wish to remain on their current regime. The reasons for switching should be explained clearly, but they may not be reassured that other inhalers will be as effective. Some may have tried a range of inhalers previously before settling on their present regime. It is important to respect individual choices where possible.

\section{Distributive Justice}

Distributive justice requires consideration of fairness and the broader population consequences of a choice, in addition to the impact on the individual patient. Although the support needed for the initiation of any inhaler is broadly similar in terms of education and explanation to ensure appropriate technique, there is likely to be some opportunity cost to switching inhalers. It may be sensible to build this into annual reviews rather that attempting to switch a whole population at once. Avoiding the initiation of these products can of course start immediately.

It's nearly 70 years since Philip Morris vice president George Weissman announced that if the company had any thought or knowledge that in any way they were selling a product harmful to consumers, they would stop business immediately. ${ }^{20}$ Rather than do this, the tobacco industry have denied the science, aggressively marketed cigarettes to young people and consistently opposed tobacco control measures. The attempt by the industry to present itself as promoting healthcare while simultaneously profiting massively from cigarettes is obscene. Moreover, although the burden of tobacco production falls most heavily in poorer countries, profits accrue in the rich. ${ }^{3}$

The tobacco industry makes $£ 900$ million profit /year on UK sales alone and has a much higher profit margin $(50-70 \%)$ than other products such as food and household goods (typically $12-20 \%$ ). ${ }^{12}$ This represents a substantial market failure, as the industry is only profitable because it is able to avoid paying for the external costs of its products - the global societal costs of tobacco are estimated to be more than \$2 Trillion/year. ${ }^{21}$ Based on market share, PMI should be liable for at least $\$ 240$ billion/year of this. Rather than engaging in expansion into the healthcare sector, the tobacco industry must instead be forced to pay to put right the harm it has caused. The fact that PMI are in a position to takeover Vectura highlights the need for the government to take forward the proposed polluter pays levy on tobacco industry profits. ${ }^{22}$

\section{Conclusion}

There are a range of alternative inhalers available that people currently using products that provide income to Vectura could switch to, now that it has been acquired by PMI. A consideration based on beneficence, non-maleficence, autonomy, and distributive justice demonstrates strong ethical reasons to support this switch, which can be achieved without any significant risk to patient outcomes.

\section{Acknowledgments}

We thank Olivia Fulton for the permission to cite her tweet. Preprint published on Authorea 24/8/2021 DOI: 10.22541/au.162981195.55902458/v1.

\section{Author Contributions}

All authors made a significant contribution to the work reported, whether that is in the conception, study design, execution, acquisition of data, analysis and interpretation, or in all these areas; took part in drafting, revising or critically reviewing the article; gave final approval of the version to be published; have agreed on the journal to which the article has been submitted; and agree to be accountable for all aspects of the work.

\section{Funding}

No external support was received for this paper. 


\section{Disclosure}

NSH reports no conflicts of interest related to this work. TGDC has received sponsorship and reimbursement for travel expenses to attend the ERS congress from GSK and Napp. His employer has received payment for his time from AstraZeneca, Boehringer, Chiesi, GSK, Insmed, Napp, Novartis - for teaching and consultancy. The authors report no other conflicts of interest in this work.

\section{References}

1. 17th World Conference on Tobacco or Health. Cape Town declaration on human rights and a tobacco-free world; 2018. Available from: https://unfairtobacco.org/en/cape-town-declaration/. Accessed October 15, 2021.

2. Murray CJL, Aravkin AY, Zheng P, et al. Global burden of 87 risk factors in 204 countries and territories, 1990-2019: a systematic analysis for the Global Burden of Disease Study 2019. Lancet. 2020;396:1223-1249.

3. Zafeiridou M, Hopkinson NS, Voulvoulis N. Cigarette smoking: an assessment of tobacco's global environmental footprint across its entire supply chain. Environ Sci Technol. 2018;52:8087-8094. doi:10.1021/acs.est.8b01533

4. UN Development Programme. The WHO framework convention on tobacco control an accelerator for sustainable development; 2017. Available from: http://www.undp.org/content/undp/en/home/library page/hiv-aids/-the-who-framework-convention-on-tobacco-control-an -accelerator-.html. Accessed October 15, 2021.

5. Philip Morris International. Investor information July 2021; 2021. Available from: https://philipmorrisinternational.gcs-web.com/static-files /ded59402-2667-402a-9635-40579f0eaa40. Accessed October 15, 2021.

6. Agrawal S. Proposed takeover of Vectura by Philip Morris International. BMJ. 2021;374:n2235.

7. European Respiratory Society. ERS response to the proposed acquisition of Vectura by Philip Morris International; 2021. Available from: https://www.ersnet.org/news-and-features/news/ers-response-to-theproposed-acquisition-of-vectura-by-philip-morris-international/. Accessed October 15, 2021.

8. British Thoracic Society. BTS statement: proposed takeover of Vectura by Philip Morris International; 2021. Available from: https:/www.britthoracic.org.uk/news/2021/bts-statement-proposed-takeover-of-vectura -by-philip-morris-international/. Accessed October 15, 2021.

9. Vectura. Vectura PLC - track record; 2021. Available from: https://www vectura.com/about-vectura/track-record/. Acccessed August 20, 2021.

10. Vectura. Vectura Group plc annual report and accounts 2020; 2021. Available from: https:/www.vectura.com/wp-content/uploads/2021/ 04/Vectura-Group-plc-Annual-Report-and-Accounts-2020.pdf. Accessed August 20, 2021.
11. National Institute for Clinical Excellence. Shared decision making NICE guideline [NG197]; 2021. Available from: https:/www.nice. org.uk/guidance/NG197. Accessed October 15, 2021.

12. All Party Parliamentary Group on Smoking and Health. Delivering a smokefree 2030: the all party parliamentary group on smoking and health recommendations for the tobacco control plan 2021; 2021. Available from: https://ash.org.uk/about-ash/all-party-parliamentarygroup-on-smoking-health/inquiries-reports/deliveringas f2030appgtcp2021/. Accessed October 15, 2021.

13. Hopkinson NS, Molyneux A, Pink J, et al. Chronic obstructive pulmonary disease: diagnosis and management: summary of updated NICE guidance. BMJ. 2019;366:14486. doi:10.1136/bmj.14486

14. Crompton GK, Barnes PJ, Broeders M, et al. The need to improve inhalation technique in Europe: a report from the Aerosol Drug Management Improvement Team. Respir Med. 2006;100:1479-1494. doi:10.1016/j.rmed.2006.01.008

15. Lavorini F, Magnan A, Christophe Dubus J, et al. Effect of incorrect use of dry powder inhalers on management of patients with asthma and COPD. Respir Med. 2008;102:593-604. doi:10.1016/j.rmed.2007.11.003

16. Usmani O, Capstick T, Saleem A, et al. Choosing an appropriate inhaler device for the treatment of adults with asthma or COPD; 2020. Available from: https:/www.guidelines.co.uk/respiratory/inha ler-choice-guideline/455503.article. Accessed October 15, 2021.

17. Moodie C, Sinclair L, Mackintosh AM, et al. How tobacco companies are perceived within the United Kingdom: an online panel. Nicotine Tob Res. 2016;18:1766-1772. doi:10.1093/ntr/ntw024

18. Liew K, Wilkinson A. P280 How do we choose inhalers? Patient and physician perspectives on environmental, financial and ease-of-use factors. Thorax. 2017;72:A235-A237.

19. Fulton O. Tweet about PMI takeover of Vectura; 2021. Available from: https://witter.com/just_TUX/status/1426450284851630081?s= 20. Accessed October 15, 2021.

20. Cummings KM. A promise is a promise. Tob Control. 2003;12:117-118. doi:10.1136/tc.12.2.117

21. The McKinsey Global Institute. Overcoming obesity: an initial economic analysis; 2014. Available from: http://www.mckinsey.com/ insights/economic_studies/how_the_world_could_better_fight_obe sity. Accessed October 15, 2021.

22. Hopkinson NS. The path to a smoke-free England by 2030. BMJ. 2020;368:m518. doi:10.1136/bmj.m518

23. Vectura. Vectura highlights update made by Hikma on launch of generic Advair Diskus ${ }^{\circledR} ; 2021$. Available from: https://ir.q4europe. com/Solutions/VecturaIntranet/3832/newsArticle.aspx?storyid= 15036321. Accessed October 15, 2021.

24. Rowex. Package leaflet: AirBuFo ${ }^{\circledR}$ Forspiro $^{\circledR} 160$ microgram $/ 4.5$ microgram/dose inhalation powder, pre-dispensed. last revision; 2018. Available from: https:/www.hpra.ie/img/uploaded/swedocuments/ 2208694.PA0711 284001.418 b6375-936e-4333-b543-e4c22f605a13. 000001AirBuFo\%20PIL.180731.pdf. Accessed October 15, 2021.

\section{Publish your work in this journal}

The International Journal of COPD is an international, peer-reviewed journal of therapeutics and pharmacology focusing on concise rapid reporting of clinical studies and reviews in COPD. Special focus is given to the pathophysiological processes underlying the disease, intervention programs, patient focused education, and self management protocols. This journal is indexed on PubMed Central, MedLine and CAS. The manuscript management system is completely online and includes a very quick and fair peer-review system, which is all easy to use. Visit http://www.dovepress.com/testimonials.php to read real quotes from published authors. 